Canadian Journal of Higher Education Revue canadienne d'enseignement supérieur

Volume 48, No. 1, 2018, pages 39 - 59

\title{
Under-represented Students and the Transition to Post-secondary Education: Comparing Two Toronto Cohorts
}

\author{
Karen Robson \\ McMaster University \\ Paul Anisef \\ York University \\ Robert S. Brown \\ Toronto District School Board \\ R. C. George \\ York University
}

\begin{abstract}
Using data from two cohorts of Grade 12 students in Toronto, we examined whether the transition to post-secondary education changed between 2006 and 2011, particularly for under-represented groups. We used multilevel, multinomial logistic regressions to examine how the intersections of race and sex affect post-secondary transitions in the two cohorts. Our findings revealed that Black, Latino, and Southeast Asian students were less prepared for postsecondary education than White students. Students in these groups had lower than average GPAs, higher identification of special education needs, or lower likelihoods of taking academic-stream courses. These differences remained fairly stable between 2006 and 2011. We did, however, find that Black students were more likely than White students to confirm a place in university in 2011-a significant difference. In contrast, Southeast Asian students ex-
\end{abstract}


perienced a decline in university transition but an increase in college confirmation. We also found that race and sex were important intersections for university confirmations in the case of Blacks and for college confirmations in the case of Southeast Asians. We contextualize our findings within the policy climate of Ontario in the years spanning our two cohorts.

\section{Résumé}

En utilisant des données de deux cohortes d'élèves $12^{\mathrm{e}}$ année à Toronto, nous avons examiné si la transition vers l'éducation postsecondaire avait changé entre 2006 et 2011, particulièrement pour les groupes sous-représentés. Nous avons utilisé des régressions logistiques multinomiales et multiniveaux pour examiner comment les intersections de race et sexe influencent les transitions vers l'éducation postsecondaire dans les deux cohortes. Nos résultats ont montré que les étudiants noirs, latins et sud-asiatiques étaient moins préparés à poursuivre des études postsecondaires. Les étudiants de ces groupes avaient des moyennes cumulatives inférieures, des taux plus élevés d'identification des besoins spéciaux et/ou étaient moins susceptibles d'être dans les cours de niveau universitaire. Ces différences restaient assez stables entre 2006 et 2011. Cependant, nous avons constaté que en 2001 les étudiants noirs étaient plus susceptibles de s'inscrire dans une université que les étudiants blancs-une différence significative. Par contre, les transitions vers l'université avaient diminué pour les étudiants d'Asie du Sud-Est, mais les acceptations des offres aux collèges avaient augmenté. Nos résultats ont également montré que la race et le sexe étaient des intersections importantes pour les confirmations de l'université dans le cas des étudiants noirs et les confirmations des collèges dans le cas des étudiants de l'Asie du Sud-Est. Nous contextualisons nos résultats dans le climat politique de l'Ontario au cours des années qui suivent nos deux cohortes.

\section{Introduction}

In this paper, we examined whether there was an increase in under-represented student groups in post-secondary enrolments in Ontario between 2006 and 2011. By "underrepresented," we mean student subgroups whose representation in colleges and universities has been significantly lower than the proportion of their respective populations in Ontario society. While we focused primarily on race and gender, these groups can also include disabled students and students from low-income homes. The time points of 2006 and 2011 represent two recent student cohorts on which data were collected by the Toronto District School Board (TDSB) in the form of a student census. Around and between these years, a number of policies in the two ministries responsible for education in Ontario were enacted or revised in a way that would potentially affect the educational experiences of young Ontarians, particularly with regard to the issues of inclusiveness and equity. Such policies, if effective, would assist in increasing the numbers of traditionally under-represented students in Ontario post-secondary institutions. 


\section{Determinants of PSE in Canada}

In Canada, the topic of access to post-secondary education (PSE) has been taken up by a variety of researchers, both academic and applied. Thorough literature reviews on the determinants of attending PSE in Canada have been undertaken by De Broucker (2005) and Cheung (2007), and a number of established predictors of participation in PSE have been consistently identified in these reviews: parental education, financial status of the family, gender, visible minority status, and region. Finnie, Lascelles, and Sweetman (2005), Finnie, Mueller, Sweetman, and Usher (2008), and Finnie, Mueller, and Sweetman (2010) have also been responsible for a large breadth of research on the determinants of Canadian PSE, finding that high school grades, family background (particularly parental levels of education), educational aspirations, and attitudes toward education were also strong predictors. Finnie and Mueller (2014), focusing on generations of immigrants, found that first and second generation immigrants were more likely to attend PSE compared with those born in Canada. Other research has focused on class of immigrant as a determinant (Hou \& Bonikowska, 2016), revealing that immigrants arriving as "skilled class" were more likely than other classes (e.g., refugee, family class) to have children who attended PSE. Additional research by Finnie, Childs, and Wismer (2011) has explored the relationship between factors related to culture and social class, suggesting that the link between parental education and PSE may have more to do with cultural and social factors (e.g., valuing education) than with straightforward economic ones (Finnie, Wismer, \& Mueller, 2015). Other Canadian research has found that youth with special education needs and racialized youth-particularly those from lower socio-economic (SES) backgrounds-are less likely to attend college and university (Robson, Anisef, Brown, \& Parekh, 2014).

\section{Intersecting Determinants of PSE}

While the study of fixed characteristics and their impact on the life chances of young people furthers the general understanding of how student characteristics affect educational attainment, the assumption in such empirical applications is that the effects are additive. For example, the general finding that females are more likely to attend PSE and that the financial status of a family may also affect the likelihood of PSE attendance assumes two things: (1) that the effect of being female is the same for all females in the sample, and (2) that income affects the likelihood of attending PSE uniformly for all students in the sample. An intersectionality approach, in contrast, recognizes the interplay of multiple sites of advantages that may more fully explain the outcomes for young people. With its origins in Black feminism, an intersectional approach begins with the premise that forms of oppression (e.g., racism, sexism, and classism) overlap, and that the consequences of race/ethnicity, gender, and other fixed characteristics cannot be understood sufficiently by studying these phenomena separately (Collins, 2015). Multiple social factors can interact together to shape life-course outcomes (McCall, 2005). Thus, it is quite possible that the effect of being female on whether or not someone will attend PSE is very likely different for racialized groups than it is for Whites. Similarly, the influence that family income has on the likelihood of attending PSE may well be different if we look at its effect for different racialized groups.

Studies incorporating intersectional frameworks into quantitative approaches are scarce in educational research. American researchers examining statistical interactions 
between different status traits and their effect on educational outcomes have, however, provided some evidence that intersectionality is at play. For example, Hill et al. (2004) examined the interaction between parental academic involvement and race, finding that parental involvement was more strongly related to academic achievement for Black students in comparison with Whites. Battle and Lewis (2002) found that the role of SES in academic achievement was stronger for White students than for Black students. Similarly, Beattie (2002) also found that family SES was more strongly associated with educational attainment for White males than Black males. When examining the relationship between SES and community college enrolment among Latin Americans, O'Connor (2009) observed that SES was more strongly associated with attending community college for White students than it was for Latin American and Black students. Finally, in a Canadian context, Robson et al. (2014) showed that Black males and students with special education needs from lower (SES) backgrounds were at a much bigger disadvantage in terms of their likelihood of pursuing PSE compared with other subgroups of students.

\section{Objectives}

Prior research using Toronto District School Board (hereafter TDSB) data from 2006 revealed that race, along with sex and social class, was a very strong predictor of future PSE participation, particularly in the case of Black males (Robson et al., 2014). The availability of comparative 2011 data has allowed us to examine whether there have been any changes in under-represented groups transitioning to PSE in Toronto. Using an intersectionality approach, we were also able to explore whether changes to post-secondary transitions occurred differentially according to students' race and sex. We contextualize our findings within the provincial policy changes that occurred between 2006 and 2011, particularly those policies intended to address equity and discrimination.

\section{Toronto District School Board Student Census Analyses}

We used both the 2006 and 2011 TDSB Student Census data for comparative purposes. The Student Census, implemented in both 2006 and 2011, collected data on all students in Grades 7 to 12 in the TDSB through self-completion questionnaires. The 2006 data report on 19,081 students who were 17 years of age and enrolled in the TDSB in the fall of 2006. Students were age-appropriate for Grade 12-the age at which most Ontario students start their transition to PSE. The 2006 Student Census data were merged with TDSB administrative data, as well as that on household income from the 2001 Canadian Federal Census (matched by postal code to the Census Dissemination Area of around 300 households). In order to track the PSE transitions of the 17 year olds, data on post-secondary applications to Ontario institutions - the Ontario University Applications Centre (OUAC) and the Ontario College Applications Centre (OCAS) - were matched to individuals in the data set. Because it has been found that students will apply over multiple years (Sweet, Anisef, Brown, Walters, \& Phythian, 2010), the OUAC and OCAS information from the 2007, 2008, and 2009 application cycles was merged with the data set to determine whether students had applied and confirmed acceptance at a university or college in any of these years. Similarly, the 2011 Student Census was completed by TDSB students in Grades 7 to 12 in the fall of 2011 and was merged with TDSB administrative records. We also obtained information on OUAC and OCAS applications for three application cycles, and this information was matched to 
individuals in the 2011 Student Census data set. The use of this subsample yielded a longitudinal database of 14,091 students. In each cohort, the TDSB Student Census provided rich demographic information as well as a series of attitudinal questions. The administrative records provided us with official measures of grades and special education needs status, while the Federal Census information provided neighbourhood of residence information.

\section{Analytic Approach}

We will first present univariate statistics to examine basic demographic shifts in the cohorts. We then examine bivariate associations between race and other determinants of PSE in order to determine whether these associations changed between cohorts. Finally, we use multinomial logistic regression to examine the effect of race and sex interactions on transitions to PSE, controlling for a host of factors.

\section{Variables}

Dependent variables: College and university confirmations. We examined three possible pathways: (1) confirmed an offer of admission to an Ontario university; (2) confirmed an offer of admission to an Ontario college; and (3) neither of these two options. The term "confirmed acceptance" applies to the situation where a student has applied to a college or university, has been accepted, and has accepted the offer. It is more substantial than a simple acceptance at a university or college; it implies the additional intentionality of the student to actually attend.

Independent variables. Our main goal in this paper was to employ an intersectionality approach in examining any race and sex changes to PSE confirmations between 2006 and 2011. To do that, we focused on students' ethnoracial group, which was measured through a self-identification item that appeared in both the 2006 and 2011 Student Census data. Students were asked to select only one category that best described their racial identity and were provided the following alternatives: White, Black, East Asian, South Asian, Southeast Asian, Latin American, Middle Eastern, Mixed, Aboriginal, and Other. Aboriginal and Other were not retained in either data set and accounted for only a handful of cases. Sex of student was measured using a variable in which males were coded o and females were coded 1 . To operationalize the concept of intersectionality, we employed interaction terms (often alternatively called multiplicative terms or moderators) between sex and race. ${ }^{1}$ Interactions were used to explore one aspect of intersectionality theory. While intersectionality theory argues that sex and race affect the life chances of individuals, the theory also suggests that their unique combinations together will have differential effects, depending upon a subgroup membership. Such a statistical application allows us to operationalize different intersectional ties of students in order to examine how different combinations of fixed characteristics can affect students' life chances (McCall, 2005). As our research question encompasses the exploration of the potential of differential effects of known factors that predict PSE for students, interaction effects are a statistically sound way of examining such hypotheses. A statistically significant interaction will tell us, for example, if the effect of being Black on post-secondary confirmations is different for males and females.

Our choice of the remaining independent variables reflects the factors that previous literature has identified as critical in understanding the PSE pathways of youth in 
Canada and that were available in our data source. Special education is intended to address the academic needs of students deemed as exceptional or who have been identified by educators as having "special needs that require supports beyond those ordinarily received in the school setting" (Ontario Ministry of Education, 2017).

Students' special educational needs (SEN) can be met through accommodations and/ or program modifications. In Ontario, there are two main categories of SEN: (1) students who have an Individual Education Plan (IEP) without undergoing a formal identification process, and (2) those who have one of 12 exceptionalities, designated through an Identification, Placement, and Review Committee (IPRC) procedure involving diagnostic assessments and usually administered by a school or external psychologist. SEN was measured in this study through the use of the Education Quality and Accountability Office (EQAO) definition: that is, students who have been formally identified by an IPRC, as well as students who have an IEP. These students were coded 1, while all other students were coded o, including gifted students.

Immigrant generational status of the students was derived from information about the students' region of birth and where their parents were born. First-generation students were those who were born outside of Canada (as were their parents); second-generation students were born in Canada, but had one parent born outside Canada; and third-generation students had both parents born in Canada (Anisef, Brown, Phythian, Sweet, \& Walters, 2010).

In terms of student characteristics, high school grades were measured using Grade 11/12 marks in percentages that were obtained from the administrative database. Attitude toward education was measured with a single Likert-type item stating "I enjoy school" with the response categories "All of the time," "Often," "Sometimes," "Rarely," and "Never," and was reverse coded so that higher numbers were associated with a greater enjoyment of school. ${ }^{2}$ A variable measuring academic and applied streams in Grade 9 was included in the analysis and coded so that 1 is equal to being in the academic stream and $\mathrm{O}$ is equal to being in the applied stream.

As mentioned above, the financial status of the family has often been touted as a major defining factor in the decisions young people make about PSE. It has also been found, however, that parental education can itself be even more of an influence on PSE trajectories (Davies, Maldonado, \& Zarifa, 2014). We, therefore, included both measures in our analysis. In the case of the economic status of the family, we used median neighbourhood family income data from the 2001 and 2006 Canadian Federal Census. These figures provide crude measures of family financial status, but they give us an idea of the family SES based on the general neighbourhood income characteristics. Any conclusions about the relationship between family income and PSE in this analysis must be drawn with caution given these data limitations, as the TDSB did not collect data on the actual incomes of individual families. In terms of parental education, the students were asked about the highest educational attainment of their parents. The data were recoded into a single variable to capture the highest level of education of either parent, with possible response categories being "High School," "College," "University," and "Don't Know." The variable was dummy-coded so that 1 is equal to university or college (i.e., any PSE). 


\section{Bivariate Associations}

Because our previous research revealed a significant association between self-identified race and post-secondary confirmations (Robson et al., 2014), we also examined bivariate relationships (Table 1) between self-identified race and (1) special education needs, (2) types of courses taken, (3) Grade 11/12 marks, and (4) PSE confirmations.

Table 1.

Key Predictors of Post-secondary Attendance by Self-Identified Race, 2006 and 2011 (\%)

\begin{tabular}{|c|c|c|c|c|c|c|c|c|c|}
\hline & 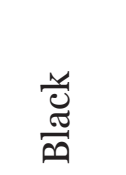 & 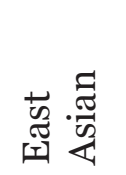 & . & 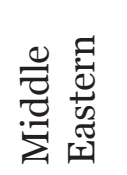 & 离 & 壳 & 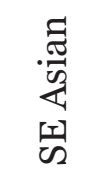 & $\stackrel{\stackrel{0}{*}}{\stackrel{7}{3}}$ & 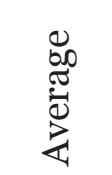 \\
\hline \multicolumn{10}{|c|}{$\begin{array}{l}\text { Racial Composi- } \\
\text { tion (\% total) }\end{array}$} \\
\hline 2006 & 10.49 & 21.59 & 2.02 & 4.80 & 4.70 & 19.90 & 2.78 & 33.73 & \\
\hline 2011 & 11.81 & 20.69 & 2.09 & 5.66 & 6.02 & 20.81 & 4.84 & 28.08 & \\
\hline \multicolumn{10}{|c|}{ Having Special } \\
\hline \multicolumn{10}{|c|}{ Education Needs } \\
\hline 2006 & 18.83 & 3.74 & 11.79 & 7.66 & 13.19 & 6.59 & 4.92 & $13 \cdot 38$ & 9.97 \\
\hline 2011 & 19.56 & $4 \cdot 35$ & 16.12 & 13.12 & 16.89 & 7.86 & 3.96 & 16.80 & 12.14 \\
\hline \multicolumn{10}{|c|}{ Taking Majority } \\
\hline \multicolumn{10}{|c|}{ Academic Courses } \\
\hline 2006 & 47.97 & 85.48 & 52.50 & 59.46 & 72.39 & $75 \cdot 7$ & 76.94 & 81.03 & $75 \cdot 33$ \\
\hline 2011 & 49.42 & 84.32 & 57.89 & 60.39 & 68.38 & 79.15 & 66.76 & 77.03 & $73 \cdot 36$ \\
\hline \multicolumn{10}{|c|}{ Grade 11/12 Marks } \\
\hline 2006 & 59.12 & 74.71 & 60.88 & 66.34 & 66.23 & 69.23 & 69.12 & 69.81 & 69.03 \\
\hline 2011 & 62.02 & 76.64 & 63.59 & 68.97 & 67.90 & 71.76 & 69.56 & 71.43 & 70.86 \\
\hline \multicolumn{10}{|c|}{ Confirm University } \\
\hline 2006 & 22.06 & 74.00 & 22.18 & 45.15 & 41.69 & 59.45 & 50.00 & 48.38 & 52.45 \\
\hline 2011 & 28.81 & 73.89 & 26.97 & 48.24 & 42.69 & 65.74 & 40.20 & 47.70 & 53.57 \\
\hline \multicolumn{9}{|c|}{ Confirm } & College \\
\hline 2006 & 24.27 & 9.22 & 21.43 & 17.49 & 17.55 & 17.86 & 21.24 & 14.47 & 15.65 \\
\hline 2011 & 30.03 & 9.90 & 23.68 & 23.21 & 20.43 & 16.91 & 29.26 & 17.70 & 18.54 \\
\hline
\end{tabular}

In terms of racial composition of the sample, White students made up the largest proportion (about $34 \%$ in 2006 to $29 \%$ in 2011), with the largest percentage increase seen in the Southeast Asian group.

Our previous research has revealed that having special education needs is a significant predictor of PSE confirmation, lessening the likelihood of confirming university (Robson et al., 2014). Moreover, we also found that racialized students, particularly Black males, were more likely to be identified as having SEN. Bearing this in mind, we examined the overall 
change in SEN status between the 2006 and 2011 cohorts. This analysis revealed that the within-group representation of students with SEN increased for all groups between 2006 and 2011, with the exception of Southeast Asian students. The groups demonstrating the largest increases were Latino, Middle Eastern, Mixed, and White students. It should be noted, however, that Black students remain the self-identified racial group with the largest representation of SEN students-nearly 19\% in 2006 to almost 20\% in 2011.

Taking a majority of courses that are "applied" rather than "academic" has also been found to be negatively associated with confirming PSE (Hamlin \& Cameron, 2015). Between 2006 and 2011, within-group representation of students in majority academic classes reveals small declines (less than 5\%) for East Asian, Mixed, and White students, but considerable decline of nearly 10\% for Southeast Asian students. Of all the self-identified race categories, Black students were least likely to be in majority academic classes (under 50\%), well below the sample average (over 70\%) in this respect. This finding is consistent across both cohorts, although slight improvements can be observed between the two cohort years.

Between 2006 and 2011, the average Grade 11/12 marks increased slightly across all self-identified racial groups of students. Black students attained the lowest average grades (59\% and 62\%) in both years, and their grade performance levels proved nearly identical to those of Latino students (with averages of $61 \%$ in 2006 and $64 \%$ in 2011). The overall average across all self-identified racial groups was around 70\% in 2006 and 2011, with East Asians averaging about 6 percentage points higher.

The overall total of students confirming a place in university was relatively unchanged between 2006 and 2011 (around 53\%). However, there were considerable differences among the racial groups. Black and Latino students confirmed university in both years at much lower rates compared to all other racial groups. Both groups, however, made considerable gains between the two years-university confirmation rose from $22 \%$ to $29 \%$ among Black students, while Latino student confirmations increased from $22 \%$ to $27 \%$. Another noticeable shift occurred among Southeast Asian students, who went from 50\% to $40 \%$ of students confirming university over the two cohorts.

Gains in college confirmations can be seen in all groups with the exception of South Asians. Overall, the increase in college confirmations between the cohorts was about 3\%. The largest increase in college confirmations was experienced by Southeast Asian students (8\%), followed by Black and Middle Eastern students (nearly 6\%). Increases in college confirmations were also observed within the other racial categories, except for a small decrease in college confirmations among South Asian students.

To summarize, there were significant differences across racial categories with respect to the incidence of SEN, the proportions choosing an academic stream, and Grade 11/12 marks. Specifically, we saw that Black and Latino students were considerably more likely to be over-represented in the SEN category, under-represented in the academic stream, and to have lower marks compared with the overall cohort averages. This has not altered significantly between 2006 and 2011, with the possible exception of the increase among Latino students with SEN. Southeast Asians students also experienced a considerable decrease of $10 \%$ in terms of choosing a majority of courses in the academic stream. In contrast, East Asian students were found to have higher than average grades, higher representation in the academic stream, and lower than average SEN identification. 
Racial differences in the factors that affect the transition to PSE by students in the TDSB are evident in the bivariate associations and also fairly consistent across both cohorts, aside from the decrease in the academic stream representation by Southeast Asians. However, there have been changes in university and college confirmations that are worthy of special mention. In particular, the greatest increase in university confirmations was experienced by Blacks, followed by South Asians and Latino students. Similarly, in terms of college confirmations, the increase among Black students was second only to that of Southeast Asian students. While Southeast Asians students' confirmation of university decreased by nearly $10 \%$ between 2006 and 2011, their college confirmations increased by $8 \%$. While still having much different educational preparedness for PSE than the TDSB averages, Black and Latino students had increased PSE confirmations across these two cohorts. Southeast Asian students are now less likely to be in the academic stream than in the past. This shift also appears to be related to the decrease in their university confirmations (and concurrent increase in college confirmations) from 2006 to 2011.

We now turn to multivariate analyses, where we can control for a variety of important factors when examining the relationship between our independent variables of interest and PSE confirmations.

\section{Multivariate Analysis}

The multivariate technique we employed is multilevel, multinomial logistic regression analyses. We chose this technique because the outcome variable of interest (i.e., university/college confirmation) is categorical in nature (confirmed university, confirmed college, confirmed neither). The use of multilevel models allowed our intercept to shift according to individual schools, with the underlying assumption that students in schools compose a secondary nested structure in our data (Robson \& Pevalin, 2016).

Our null model (results not shown) provided intraclass correlation (ICC) values of 0.14 for both 2006 and 2011, indicating that 14\% of the variation in PSE transitions was accounted for by differences between schools in both cohorts. This dropped to around 4\% after the interactions and controls were included, indicating that much of the variation between schools can be accounted for by the factors we have included in the models. Multinomial logistic regressions produce necessarily complex tables, as the dependent variable is presented as a series of nominal categories to be compared against an omitted reference category. In this case, the omitted category is "Neither University nor College." We present 2006 and 2011 findings side-by-side in order to compare the odds ratios across cohorts. Our full model is presented in Table $2 .^{3}$

Race and sex are presented first, followed by their interaction terms. It must be emphasized that when interaction terms are included in estimations, the meaning of the main effects of the composite variables changes. The main effects indicate that in 2006, East Asian, Middle Eastern, South Asian, and Southeast Asian students were more likely to attend university than Whites when sex was equal to o (male). In 2011, this group expanded to include Blacks, while Southeast Asians became no different than Whites (when sex was equal to 0). ${ }^{4}$ In the case of college, Middle Eastern students were more likely to attend college in 2011, while South Asian students were more likely to confirm college than Whites in both years (when sex was equal to 0 ). These main effects indicate a striking change between 2006 and 2011-revealing that Blacks in the later cohort are actually more likely to attend university than White males. 
Table 2.

Odds Ratios from Multilevel Multinomial Logistic Regression Predicting PSE (Reference $=$ Not Confirming University or College)

\begin{tabular}{|c|c|c|c|c|}
\hline Variable & $\begin{array}{c}2006 \\
\text { University }\end{array}$ & $\begin{array}{c}2011 \\
\text { University }\end{array}$ & $\begin{array}{c}2006 \\
\text { College }\end{array}$ & $\begin{array}{c}2011 \\
\text { College }\end{array}$ \\
\hline \multicolumn{5}{|l|}{ Ethnoracial Self ID } \\
\hline Black & 0.848 & $1.453^{* *}$ & 0.950 & 0.965 \\
\hline East Asian & $3 \cdot 478^{* * *}$ & $2.960^{* * *}$ & 1.164 & 1.004 \\
\hline Latin American & 0.874 & 0.674 & 0.987 & 0.720 \\
\hline Middle Eastern & $1.700^{* *}$ & $2.406^{* * *}$ & 0.979 & $1.545^{* *}$ \\
\hline Mixed & 1.068 & 1.069 & 1.041 & 0.878 \\
\hline South Asian & $2.942^{* * *}$ & $3.277^{* * *}$ & $1.423^{* *}$ & $1.382^{* *}$ \\
\hline Southeast Asian & $1.626^{*}$ & 1.129 & 1.480 & 1.236 \\
\hline Female & 1.061 & 1.063 & 1.036 & 1.065 \\
\hline \multicolumn{5}{|l|}{ Interactions } \\
\hline Female X Black & $1.813^{* *}$ & 1.152 & $1.426^{*}$ & $1.571^{* *}$ \\
\hline Female X East Asian & 0.793 & $0.688^{*}$ & 0.968 & 0.720 \\
\hline Female X Latin American & 0.850 & 1.817 & 1.009 & 1.779 \\
\hline Female X Middle Eastern & 1.536 & 1.087 & $1.753^{*}$ & 0.883 \\
\hline Female X Mixed & 1.141 & 0.878 & 0.864 & 0.941 \\
\hline Female X South Asian & 1.141 & 1.205 & $1.420^{*}$ & 1.196 \\
\hline Female X Southeast Asian & 1.171 & 1.327 & 1.289 & $1.782^{*}$ \\
\hline Special Education Needs & $0.741^{* *}$ & $0.504^{* * *}$ & $1.241^{* *}$ & 1.111 \\
\hline First Generation & $1.263^{*}$ & 1.096 & 1.208 & 0.916 \\
\hline Second Generation & $1.261^{* *}$ & $1.706^{* * *}$ & $1.449^{* * * *}$ & $1.471^{* * *}$ \\
\hline Parental PSE & $1.306^{* * * *}$ & $1.398^{* * *}$ & 0.955 & 0.916 \\
\hline Average Mark Grade 11 & $1.126^{* * * *}$ & $1.129^{* * *}$ & $1.027^{* * * *}$ & $1.024^{* * *}$ \\
\hline Median Family Income & 1.000 & 1.000 & $0.993^{* * * *}$ & $0.994^{* * *}$ \\
\hline Academic Stream & $9.493^{* * *}$ & $4.911^{* * *}$ & 1.126 & 0.901 \\
\hline Enjoy School & $1.098^{* *}$ & 1.029 & 1.017 & 0.976 \\
\hline$N$ & 12,433 & 14,367 & & \\
\hline AIC & 17321.8 & 20693.3 & & \\
\hline $\mathrm{BIC}$ & 17700.6 & 21079.5 & & \\
\hline Log Likelihood & -8609.9 & -10295.6 & & \\
\hline ICC & 0.042 & 0.0412 & & \\
\hline
\end{tabular}

Note. The omitted categories were White and Third Generation. ${ }^{*} p<.05,{ }^{* *} p<.01,{ }^{* * *} p<.001$ 
The overall "effect" of race and sex needs to be calculated with the main effects of the composite variables as well as the interaction term, something that is difficult to "eyeball." Thus, we provide the predicted probabilities in the form of data visualizations in Figures 1 and 2, focusing on interactions that achieved statistical significance. The reference group for all interactions is White males (which are represented as a bar in both graphs).

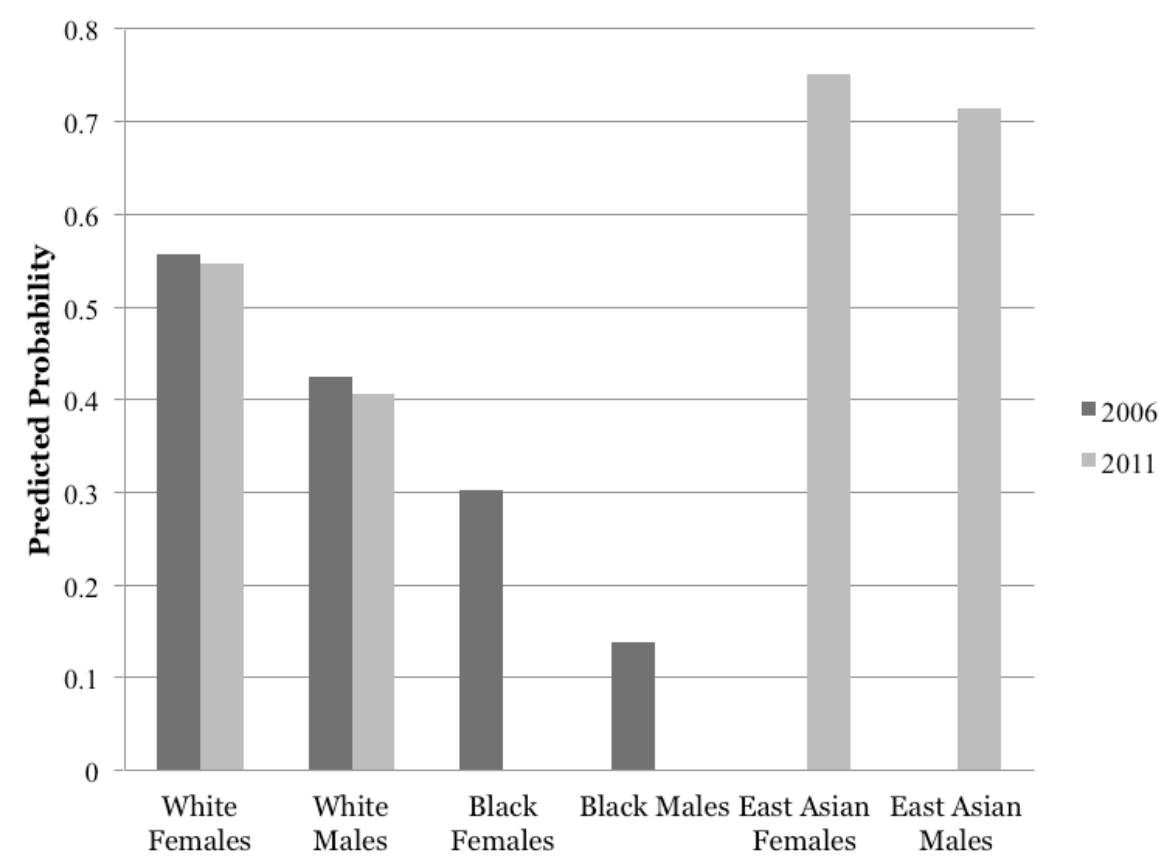

Figure 1. Predicted Probabilities of Confirming University: Race and Sex Interactions

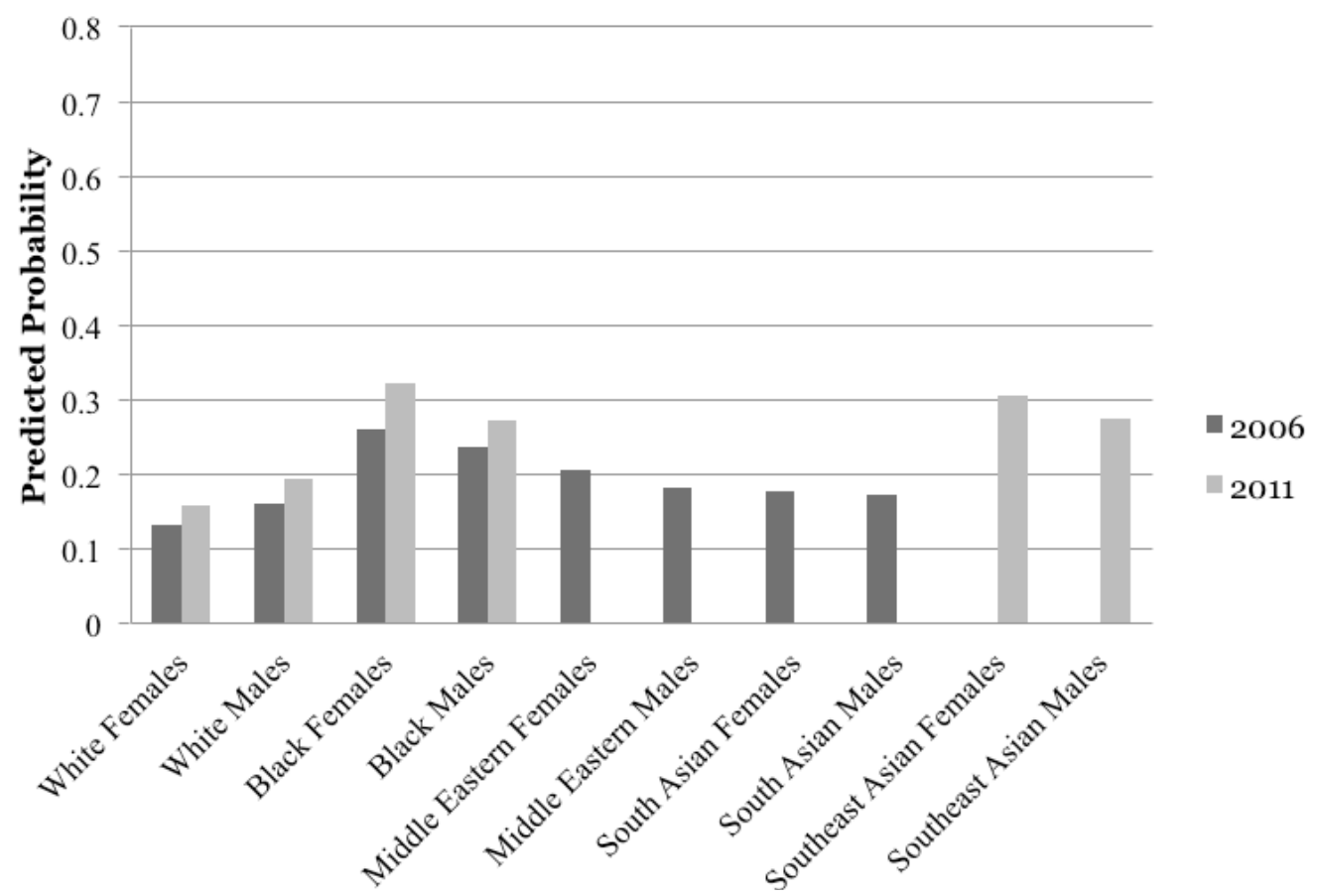

Figure 2. Predicted Probabilities of Confirming College: Race and Sex Interactions 
The first bars in Figure 1 illustrate the predicted probabilities of confirming university for Whites in both cohorts. From 2006 to 2011, there is a negligible drop in the probabilities for Whites. The interaction between Female $X$ Black for confirming university was significant in 2006, but not in 2011. This interaction demonstrated that being female differentially impacted upon race in terms of university confirmations for Blacks; the gap between the predicted probability for Black females and Black males attending university is much greater than that between White females and males. Black females were about one and a half times more likely to confirm university compared to their male counterparts in 2006. A significant interaction was also found between Female X East Asian for university attendance, this time demonstrating that the sex gap is much smaller for East Asians than the White reference group. In other words, while White females are more likely to confirm university than White males, this is not the case for East Asian females, who confirm at a rate similar to that of East Asian males.

Turning to predicted college confirmations in Figure 2, in 2006, the sex X race interaction was significant for the Black, Middle Eastern, and South Asian groups. The significant interaction between Female $X$ Black reveals that Black females were nearly one and a half times more likely to attend college than White males. Between 2006 and 2011, this relationship strengthened, with Black females even more likely to confirm college than White males. The sex differences in both years demonstrate that Black females were more likely to confirm college compared to their male counterparts. The interactions between female and the Middle Eastern and South Asian groups also reveal that the effect of race on confirmation of college differed significantly for these groups compared to White males, but the findings, when visualized, reveal little difference between the groups. As for Southeast Asian females, their probability of confirming college was nearly 1.8 times that of White males, but the sex difference between Southeast Asian females and males was very narrow in terms of confirming college.

To summarize, the interactions in Figures 1 and 2 have shown that in terms of confirming university, the significant Female X Black interaction observed in 2006 could no longer be observed in 2011, and that the sex gap between East Asians in 2011 was much smaller than that observed in Whites. In terms of college confirmations, Black females were significantly more likely to confirm than all Whites and Black males, and this relationship became stronger in 2011. The significant relationship interactions in the Middle Eastern and South Asian groups in 2006 revealed little difference between the sexes within these groups, while in 2011 Southeast Asians (females in particular) became significantly more likely to attend colleges compared to Whites.

As for the other variables in the model (used as controls), the increased negative relationship between having SEN and university confirmation is notable, reducing the odds in this outcome by around 25\% in 2006 to nearly 50\% in 2011. In terms of college confirmations, having SEN increased the odds of attendance by around $24 \%$ in 2006, but did not achieve statistical significance in 2011. Relative to third-generation immigrants, first-generation immigrants no longer had increased odds of university confirmation in 2011, although they were around 26\% more likely to confirm in 2006. However, in 2011, being second generation, relative to third, increased the odds of a university confirmation by almost $71 \%$. Average marks in Grade 11/12 continued to be strong predictors in both cohorts for both university and college confirmations, whereas parental PSE, academic stream, and enjoyment of school were important for university but not college confirmations in both years. 


\section{Discussion}

Perhaps the most striking findings in our analyses were the changing PSE confirmation patterns for Blacks and Southeast Asians. In the bivariate analyses, Black students were found, on average, to be less prepared for PSE as indicated by their having lower grades and higher rates of SEN, and they were less likely to be in academic courses in both cohorts. However, controlling for these factors, Black students ended up being more likely than White students to confirm university in 2011. Southeast Asian students, in contrast, went from being more likely to confirm university than Whites in 2006 to being no different from Whites in 2011. They also had a marked decrease in the proportion represented in the academic stream. Taking into consideration the interactions, the effect for Black females persisted in college confirmations, but not in university confirmations. For Southeast Asian females, there was an observed significance in the interaction term for college confirmations, indicating significantly higher likelihoods of Southeast Asian women choosing college. What was driving these changes?

Black students still had overall lower grades, higher rates of SEN, and were more likely to be in the applied stream in 2011-this did not change. The overall situation for these students did not improve-their successes were achieved despite their relative school situations remaining unchanged. In the case of Black students and in the absence of affirmative action admissions policies in Ontario (or Canada), it may be the case that they were getting better at navigating the "structural obstacle course" that tends to stream them into lower-ability groupings and curtails their later-life academic choices. Another possibility is that our racial categorizations have masked important demographic changes in the TDSB student population. These data do not allow us to explore this possibility at this time, but it may be that the primary country of origin of Black and Southeast Asian students had changed between the 2006 and 2011 cohorts. We were able to partially investigate this by looking at the immigrant generation statuses within these two groups in both cohorts, as the more recent immigrants to Toronto have tended to be from different countries of origin than in the past (i.e., in the case of Southeast Asian students, the Philippines rather than Vietnam; in the case of Black students, Somalia rather than the Caribbean) (Ontario Ministry of Finance, 2013). Figure 3 illustrates a marked increase in second-generation students within the Black category from 2006 to 2011-over 25\% more Black students were second generation in 2011 than in 2006. For Southeast Asian students, however, there was not much difference between the two years.

The increase in university confirmations for Blacks may be at least partially explained by the increase in second-generation students in their population. The TDSB has also documented a change in the Somali population. In the first TDSB cohort study of those who started high school in the fall of 2000 (not analyzed in this report), the majority of Somali-speaking students were born outside of Canada; in the more recent 2008 cohort, the majority of Somali-speaking students were born in Canada. During the same time, the proportion of Somali-speaking students going to PSE increased by $25 \%$ (Brown, New-

ton, \& Tam, 2015). Canadian studies have found that second-generation students tend to outperform their first- and third-generation counterparts (Abada, Hou, \& Ram, 2008; Aydemir \& Sweetman, 2007). 


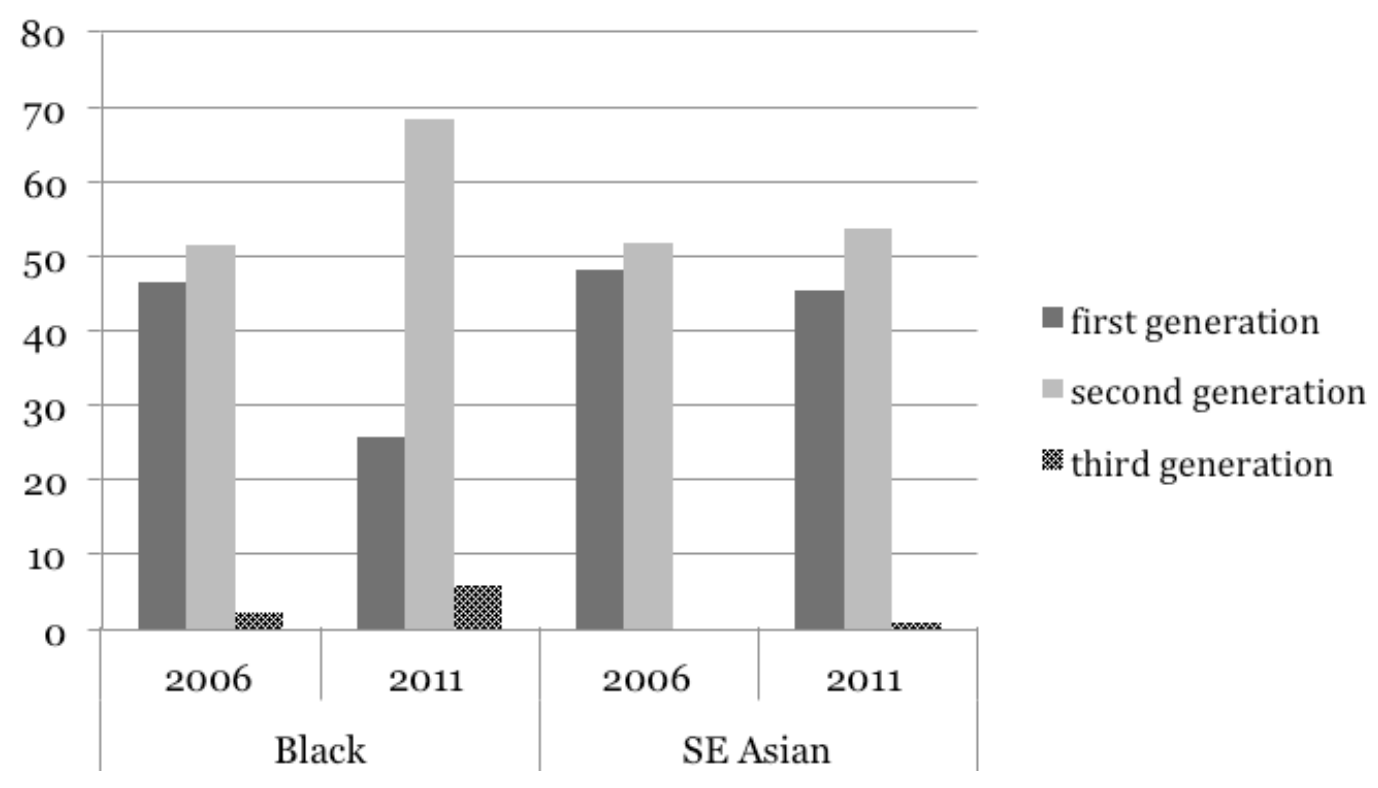

Figure 3. Immigrant Generation Breakdown of Black and Southeast Asian Students in Two TDSB Cohorts

The changes in the outcomes for Southeast Asian students are undoubtedly linked to their increased placement in the non-academic stream (Table 1). This 10\% increase over the cohorts is not coincidentally linked to their $10 \%$ decrease in not confirming university and $8 \%$ increase in confirming college. Traditionally, this group has been composed mostly of Vietnamese students, but this altered during the 2006 to 2011 time frame, with more Southeast Asian students emigrating from the Philippines. The causal mechanisms associated with the outcomes of Filipino youth are not fully understood, but are likely linked to the poorer labour market outcomes of their parents and the social mechanisms informing educational choices (Kelly, 2014).

\section{The Ontario Policy Context}

We now turn to the policy context in Ontario spanning the years of the cohorts examined here in order to consider whether policies enacted between the two cohort years may be-at least in part-responsible for some of the changes we observed, particularly for Black students. Contextually, the two student census years straddle important social and political events in Toronto. The provincial Liberals-like many provincial governments across the country-were pursuing policies that target "access." Many such initiatives were developed after high-profile crimes involving racialized youth (including shootings at TDSB schools in 2007, 2008, and 2010) spearheaded discussions about the limited life choices being presented to Black male youth in Toronto. The Ontario Ministry of Education also introduced its Equity and Inclusive Education Strategy in 2009, which was a direct response to a report commissioned on youth violence in 2008 (McMurtry \& Curling, 2008). The focus of this strategy was to recognize the many sites of diversity in the student population and to promote equity and inclusive education (Ontario Ministry of Education, 2009b). 
In 2005, the Liberal government in Ontario introduced the Reaching Higher Plan, which aimed to increase accountability, access, and quality of post-secondary education (Office of the Premier, 2005). Reporting agreements with post-secondary institutions since 2006 have become an accountability tool for demonstrating that goals of increased access, quality, and accountability are being met. Further policies developed by the Ministry of Advanced Education and Skills Development, such as the Differentiation Framework (2013), ${ }^{5}$ have also emphasized increasing access for under-represented groups, particularly Aboriginal, francophone, disabled, and first-generation students.

In terms of policies explicitly combating racism, Policy Program Memorandum (PPM) 119 was first introduced in 1993 under Bob Rae's NDP government. The emergence of this policy has been traced back to the Yonge Street Riots of 1992 and the subsequent Lewis (1992) report that identified a problem of anti-Black racism in southern Ontario. Shortly thereafter, the provincial government announced PPM 119, "Development and Implementation of School Board Policies on Anti-Racism and Ethnocultural Equity." Included in this directive was the requirement of all boards to develop a race relations policy (Dei, 2003). When the Tories (under Mike Harris) took office in 1995, however, much of the legislation was repealed (Dei, 2003).

Under Harris, the Safe Schools Act was enacted into law in 2000, which created a set of regulations around the punishment and suspension of students for disciplinary infractions. Not long after the act came into force, a steady rise in suspensions and expulsions was observed in ministry statistics, which climbed yearly (Winton, 2012). After the Liberals took office in 2004, a review of the act was undertaken. In 2005, the Ontario Human Rights Commission found that the discipline-related policies were being disproportionately exercised against racialized students and students with disabilities (Ontario Human Rights Commission, 2005). In 2007, the Safe Schools Act was amended so that expulsions were no longer mandatory and mitigating factors had to be taken into consideration by the principal. This resulted in a steady decrease in the number of suspensions (Winton, 2012). Importantly, students in the TDSB 2006 cohort would have been subjected to the original Safe Schools Act and a "toothless" PPM 119 (Dei, 2003). In 2009, then-Ontario education minister Kathleen Wynne amended PPM 119-renamed "Developing and Implementing Equity and Inclusive Education Policies in Ontario Schools" - to state:

No. 119 (1993) sought to equip students with the knowledge, skills, and attitudes to live in an increasingly diverse world, appreciate diversity, and reject discriminatory behaviours and attitudes.... [It] is now recognized that such factors as race, sexual orientation, physical or mental disability, sex and class can intersect to create additional barriers for some students. (Ontario Ministry of Education, 2009a, p. 3)

PPM 119 was also further updated in 2013 to include gender identity and gender expression in the dimensions of diversity covered by the Ontario Human Rights Code.

Students in the 2006 cohort experienced a considerably different policy climate than did those of the 2011 cohort. Between 2006 and 2011, amendments were made to the disciplinary procedures, and discussion about equity issues re-entered government discourse. Given the timeline of these policies (and the public interest around them, particularly the Ontario Human Rights Commission Inquiry), it would be reasonable to surmise that these policy changes would result in positive changes to school climate, particularly 
with regard to the treatment of racialized and SEN students. The amendments to PPM 119 actually embraced the idea of intersectionality, based on the understanding that axes of difference can characterize students and that these differences can make them vulnerable to discrimination.

\section{Conclusions}

While our analyses of the 2006 and 2011 TDSB Student Census data showed improvements for Black students in terms of PSE confirmations, the bivariate analyses still revealed that Black (and Latin American) students had much lower average grades, higher instances of SEN, and were considerably less likely than other students to be in a majority of academic courses. The situation for Southeast Asian students also deteriorated somewhat between the two cohorts, demonstrating a 10\% decrease in the proportion of those who were taking a majority of academic courses. Inequality in later-life outcomes is rooted in early-life disadvantages, and while Black, Latino, and Southeast Asian students are certainly exhibiting resilience (as demonstrated by the changes in 2006 to 2011), it is only reasonable to assume that if their earlier school experiences could be improved, this would increase their later-life chances as well. Programs to improve the achievement of Black, Latino, and Southeast Asian students in elementary school would be a logical starting point. An intersectional policy approach suggests that targeting the most vulnerable groups-in this case Black, Latino American, and Southeast Asian students-is the best way of activating change (Museus \& Griffin, 2011).

Our analyses point out the value of an intersectionality approach and the need to tune in to more than one characteristic at a time. Our findings, however, are limited to the case of the TDSB, and therefore, cannot be generalized across the country or even across the province. Because our data source contained too few students (less than 100) who selfidentified as Aboriginal, our findings also neglect to address a particularly marginalized demographic in Canada. In 2007, the Ontario First Nation, Métis, and Inuit Education Policy Framework was introduced by the Ontario Ministry of Education, with one of the priorities being to improve achievement among Aboriginal students. As well, the Ministry of Advanced Education and Skills Development launched the Aboriginal Postsecondary Education and Training Policy Framework in 2011 as an attempt to improve the learning and employment outcomes for Aboriginal youth. Our analyses did not allow us to investigate whether there was any evidence of improvement for Aboriginal students that may be attributed to such policies. More research also needs to be done on the intersections of social class and disability with race and gender, as we have only scratched the surface on identifying the intersections that affect PSE. The complexities revealed by our analysis underscore the need for generating locally developed policies and strategies that recognize and are sensitive to multiple axes of difference among marginalized student groups.

\section{Notes}

1. Intersectionality theory often focuses on (a minimum of) race, gender, and class. We, however, only focus on race and gender for two reasons. First, employing all possible race $X$ sex $X$ class interactions would make for a very unwieldy model (with around 28 interactions), where substantial effects would be masked by a lot of statistical "noise." 
Second, our available measure of income is not ideal. It is a neighbourhood characteristic rather than a student characteristic and is therefore more appropriately used as a control variable and a proxy for potential economic resources.

2. While educational aspirations held by the student were, along with the student's perception of parental educational aspirations, identified earlier as being important determinants of PSE, the items measuring these variables in the data set were limited to those students who completed "Form B," that is, half the data set. Including these variables would have diminished our sample by half and, more crucially, our subset of SEN students by half. Therefore, the inclusion of these specific variables was not undertaken.

3. See Appendix 1 for unstandardized coefficients and standard errors.

4. When interactions are included in statistical models, the interpretation of their composite main effects changes from how they would be interpreted if there were no interactions.

5. The document outlining the policy is dated 2013, but changes to access and accountability have informed the ministry's practices with regard to post-secondary institutions' reporting practices since 2008.

\section{Acknowledgements}

The authors would like to acknowledge that this research was funded by the Ontario Human Capital and Innovation Fund.

\section{References}

Abada, T., Hou, F., \& Ram, B. (2008). Ethnic differences in educational attainment among the children of Canadian immigrants. Sandbox Journal for Canadian Journal of Sociology, 34(1), 1-30.

Anisef, P., Brown, R. S., Phythian, K., Sweet, R., \& Walters, D. (2010). Early school leaving among immigrants in Toronto secondary schools. Canadian Review of Sociology, 47(2), 103-128.

Aydemir, A., \& Sweetman, A. (2007). First- and second-generation immigrant educational attainment and labor market outcomes: A comparison of the United States and Canada. In B. R. Chiswick (Ed.), Immigration (pp. 215-270). Research in Labor Economics, 27. Bingley, UK: Emerald Group Publishing.

Battle, J., \& Lewis, M. (2002). The increasing significance of class: The relative effects of race and socioeconomic status on academic achievement. Journal of Poverty, 6, 21-35.

Beattie, I. R. (2002). Are all "adolescent econometricians" created equal? Racial, class, and gender differences in college enrollment. Sociology of Education, 75(1), 19-43.

Brown, R., Newton, L., \& Tam, G. (2015). The Toronto District School Board's student group overviews: Aboriginal heritage, Afghan, Portuguese-speaking, Somali-speaking, and Spanish-speaking students (Research Report No. 14/15-31). Toronto, ON: Toronto District School Board.

Cheung, S. (2007). Education decisions of Canadian youth. Toronto, ON: Higher Education Quality Council of Ontario. 
Collins, P. H. (2015). Intersectionality's definitional dilemmas. Annual Review of Sociology, 41, 1-20.

Davies, S., Maldonado, V., \& Zarifa, D. (2014). Effectively maintaining inequality in Toronto: Predicting student destinations in Ontario universities. Canadian Review of Sociology/Revue canadienne de sociologie, 51(1), 22-53.

De Broucker, P. (2005). Getting there and staying there: Low-income students and post-secondary education. Ottawa, ON: Canadian Policy Research Network.

Dei, G. J. S. (2003). Challenges for Anti-Racist Educators in Ontario Today. Orbit, 33(3), 2-5.

Finnie, R., Lascelles, E., \& Sweetman, E. (2005). Who goes? The direct and indirect effects of family background on access to post-secondary education (Analytical Studies Branch research paper series, catalogue no. 11Foo19MIE No. 237). Ottawa, ON: Statistics Canada.

Finnie, R., Mueller, R., Sweetman, A., \& Usher, A. (2008). Who goes? Who stays? What matters? Accessing and persisting in post-secondary education in Canada. Montreal, QC: McGill-Queen's University Press.

Finnie, R., Frenette, M., Mueller, R., \& Sweetman, A. (2010). Pursuing higher education in Canada: Economic, social, and policy dimensions. Montreal, QC: McGillQueen's University Press.

Finnie, R., Childs, S., \& Wismer, A. (2011). Under-represented groups in postsecondary education in Ontario: Evidence from the youth in transition survey. Toronto, ON: Higher Education Quality Council of Ontario.

Finnie, R., \& Mueller, R. (2014). Access to post-secondary education among the first and second generation children of Canadian immigrants. Abstract retrieved from the Social Sciences Research Network (SSRN): https://ssrn.com/abstract=2462339

Finnie, R., Wismer, A., \& Mueller, R. E. (2015). Access and Barriers to Postsecondary Education: Evidence from the Youth in Transition Survey. Canadian Journal of Higher Education, 45(2), 229-262.

Hamlin, D., \& Cameron, D. (2015). Applied or academic: High impact decisions for Ontario students (Research Report). Toronto, ON: People for Education.

Hill, N. E., Castellino, D. R., Lansford, J. E., Nowlin, P., Dodge, K. A., Bates, J. E., \& Pettit, G. S. (2004). Parent academic involvement as related to school behavior, achievement, and aspirations: Demographic variations across adolescence. Child Development, 75(5), 1491-1509.

Hou, F., \& Bonikowska, A. (2016). Educational attainment of childhood immigrants: How does immigration type matter? Journal of Ethnic and Migration Studies, 1-19. http://dx.doi.org/10.1080/1369183X.2016.1243462

Kelly, P. (2014). Understanding intergenerational social mobility: Filipino youth in Canada (IRPP Study No. 45). Montreal, QC: Institute for Research on Public Policy. Retrieved from http://irpp.org/wp-content/uploads/assets/research/ diversity-immigration-and-integration/filipino-youth/kelly-feb-2014.pdf 
Lewis, S. (1992). Report of the advisor on race relations to the premier of Ontario, Bob Rae. Retrieved from http://www.siu.on.ca/pdfs/report_of_the_advisor_on_race_ relations_to_the_premier_of_ontario_bob_rae.pdf

McCall, L. (2005). The complexity of intersectionality. Signs, 3O(3), 1771-1800.

McMurtry, R., \& Curling, A. (2008). The review of the roots of youth violence: Vol. 2. Executive summary. Toronto, ON: Queen's Printer for Ontario.

Museus, S., \& Griffin, K. (2011). Mapping the margins in higher education: On the promise of intersectionality frameworks in research and discourse. New Directions for Institutional Research, 151, 5-13.

O'Connor, N. (2009). Hispanic origin, socio-economic status, and community college enrollment. The Journal of Higher Education, 8o(2), 121-145.

Office of the Premier. (2005). Reaching higher: The McGuinty government plan for postsecondary education (News release). Retrieved from https://news.ontario.ca/opo /en/2005/o5/reaching-higher-the-mcguinty-government-plan-for-postsecondaryeducation.html

Ontario Human Rights Commission. (2005). Commission to investigate application of safe schools legislation and policies (News release). Retrieved from http://www.ohrc. on.ca

Ontario Ministry of Advanced Education and Skills Development. (2011). Aboriginal postsecondary education and training policy framework. Retrieved from http://www. tcu.gov.on.ca/pepg/publications/APETPFramework.pdf

Ontario Ministry of Training, Colleges and Universities (2013). Ontario's Differentiation Policy Framework for Postsecondary Education. Ontario Ministry of Training, Colleges and Universities. Retrieved from http://www2.tcu.gov.on.ca/pepg/ publications/PolicyFramework_PostSec.

Ontario Ministry of Education. (2007). Ontario First Nation, Métis, and Inuit education policy framework, 2007. Retrieved from http://www.edu.gov.on.ca/eng/ aboriginal /fnmiframework.pdf

Ontario Ministry of Education. (2009a). Policy/program memorandum 119: Developing and implementing equity and inclusive education policies in Ontario schools. Retrieved from http://www.edu.gov.on.ca/eng/policyfunding/inclusiveguide.pdf

Ontario Ministry of Education. (2009b). Realizing the promise of diversity: Ontario's equity and inclusive education strategy. Retrieved from http://www.edu.gov.on.ca/eng/ policyfunding/equity.pdf

Ontario Ministry of Education. (2017). An introduction to special education in Ontario. Retrieved from http://www.edu.gov.on.ca/eng/general/elemsec/speced/ontario.html

Ontario Ministry of Finance. (2013). 2011 National household survey highlights. Fact Sheet 1. Retrieved from http://www.fin.gov.on.ca/en/economy/demographics /census/nhshi11-1.html

Ontario Ministry of Training, Colleges and Universities. (2011). Aboriginal postsecondary education and training policy framework. Toronto, ON: Queen's Printer for Ontario. 
Ontario Ministry of Training, Colleges and Universities. (2013). Ontario's differentiation policy framework for postsecondary education. Retrieved from http:// www2.tcu.gov.on.ca/pepg/publications/PolicyFramework_PostSec.pdf

Robson, K., Anisef, P., Brown, R. S., \& Parekh, G. (2014). The intersectionality of postsecondary pathways: The case of high school students with special education needs. Canadian Review of Sociology, 51(3), 193-215.

Robson, K., \& Pevalin, D. (2016). Multilevel modelling in plain language. London, England: Sage Publications.

Sweet, R., Anisef, P., Brown, R., Walters, D., \& Phythian, K. (2010). Post-high school pathways of immigrant youth. Toronto, ON: Higher Education Quality Council of Ontario.

Winton, S. (2012). From zero tolerance to student success in Ontario, Canada. Educational Policy, 27(3), 467-498.

\section{Contact Information}

Karen Robson

Department of Sociology

McMaster University

klrobson@mcmaster.ca

Karen Robson is an associate professor and Ontario Research Chair in Educational Achievement and At-Risk Youth in the Department of Sociology at McMaster University. Her research focuses on the factors that impact upon the transition of secondary students to post-secondary education.

Paul Anisef is a professor of sociology (retired) at York University and a former director of the Centre of Excellence for Research on Settlement and Immigration, York University. His extensive research agenda has embraced a wide range of areas, including a 25year longitudinal study of Ontario high school students; the settlement and integration of immigrant youth; an examination of the post-secondary pathways of native-born and immigrant youth; and a social inclusion analysis of the role played by institutions (e.g., housing, health) in facilitating the integration of recent immigrants to Toronto.

Robert S. Brown has worked in applied research for over 30 years, in media research, market research, and education research. He is a research co-ordinator at the Toronto Board of Education and adjunct professor at York University in the Faculty of Education and in Critical Disability Studies. He has authored or co-authored works in a number of fields, including education, psychology, sociology, and medicine.

R. C. George is a doctoral candidate in sociology at York University. Her doctoral research explores the specific social, educational, and athletic experiences of Black Canadian female athletes who have pursued US athletic scholarships. 


\section{Appendix 1}

Unstandardized Coefficients for Multilevel Multinomial Logistic Regression Predicting PSE $($ Reference $=$ Not Confirming University or College $)$

\begin{tabular}{|c|c|c|c|c|}
\hline Variable & $\begin{array}{c}2006 \\
\text { University }\end{array}$ & $\begin{array}{c}2011 \\
\text { University }\end{array}$ & $\begin{array}{c}2006 \\
\text { College }\end{array}$ & $\begin{array}{c}2011 \\
\text { College }\end{array}$ \\
\hline \multicolumn{5}{|l|}{ Ethnoracial Self ID } \\
\hline Black & $-0.164(0.168)$ & $0.374(0.135)$ & $-0.052(0.134)$ & $-0.036(0.118)$ \\
\hline East Asian & $1.245(0.127)$ & $1.085(0.123)$ & $0.152(0.142)$ & $0.004(0.136)$ \\
\hline Latin American & $-0.134(0.312)$ & $-0.395(0.272)$ & $-0.013(0.254)$ & $-0.328(0.227)$ \\
\hline Middle Eastern & $0.531(0.190)$ & $0.888(0.169)$ & $-0.021(0.193)$ & $0.435(0.160)$ \\
\hline Mixed & $0.066(0.192)$ & $0.067(0.164)$ & $0.039(0.180)$ & $-0.130(0.159)$ \\
\hline South Asian & $1.080(0.127)$ & $1.187(.0120)$ & $0.353(0.130)$ & $0.324(0.121)$ \\
\hline Southeast Asian & $0.486(0.243)$ & $0.121(0.002)$ & $0.392(0.235)$ & $0.212(0.157)$ \\
\hline Female & $0.059(0.087)$ & $0.061(0.093)$ & $0.036(0.099)$ & $0.063(0.097)$ \\
\hline \multicolumn{5}{|l|}{ Interactions } \\
\hline Female X Black & $0.595(0.207)$ & $0.142(0.175)$ & $0.355(0.175)$ & $0.452(0.156)$ \\
\hline Female X East Asian & $-0.231(0.165)$ & $-0.373(0.154)$ & $-0.033(0.196)$ & $-0.328(0.182)$ \\
\hline Female X Latin American & $-0.162(0.424)$ & $0.597(0.371)$ & $0.009(0.352)$ & $0.576(0.322)$ \\
\hline Female X Middle Eastern & $0.430(0.279)$ & $0.083(0.233)$ & $0.561(0.278)$ & $-0.124(0.230)$ \\
\hline Female X Mixed & $0.132(0.258)$ & $-0.30(0.218)$ & $-0.146(0.264)$ & $-0.061(0.216)$ \\
\hline Female X South Asian & $0.132(0.157)$ & $0.186(0.153)$ & $0.351(0.167)$ & $0.179(0.163)$ \\
\hline Female X Southeast Asian & $0.159(0.332)$ & $0.283(0.250)$ & $0.254(0.334)$ & $0.578(0.236)$ \\
\hline Special Education Needs & $-0.300(0.111)$ & $-0.686(0.093)$ & $0.192(0.087)$ & $0.106(0.072)$ \\
\hline First Generation & $0.233(0.094)$ & $0.091(0.093)$ & $0.189(0.105)$ & -0.088 (0.097) \\
\hline Second Generation & $0.231(0.859)$ & $0.534(0.085)$ & $0.371(0.095)$ & $0.386(0.087)$ \\
\hline Parental PSE & $0.267(0.063)$ & $0.335(0.058)$ & $-0.046(0.062)$ & $-0.087(0.056)$ \\
\hline Average Mark Grade 11 & $0.118(0.003)$ & $0.121(0.003)$ & $0.0267(0.002)$ & $0.0236(0.002)$ \\
\hline Median Family Income & $-0.000(0.001)$ & $0.000(0.001)$ & $-0.007(0.002)$ & $-0.006(0.001)$ \\
\hline Academic Stream & $2.251(0.096)$ & 1.591 (0.069) & $0.118(0.71)$ & $-0.105(0.061)$ \\
\hline Enjoy School & $0.094(0.030)$ & $0.029(0.028)$ & $0.017(0.031)$ & $-0.024(0.027)$ \\
\hline Constant & $-11.743(0.286)$ & $-11.275(0.312)$ & & \\
\hline $\mathrm{N}$ & 12,433 & 14,367 & & \\
\hline
\end{tabular}

Note. The omitted categories were White and Third Generation. Parentheses indicate standard errors. 